\title{
Effect of Diet upon Intestinal Disaccharidases and Disaccharide Absorption *
}

\author{
J. J. Deren, $\dagger$ S. A. Broitman, and N. Zamcheck $\ddagger$ \\ (From the Gastroenterology Laboratory, Mallory Institute of Pathology; the Second and \\ Fourth [Harvard] Medical Services, Boston City Hospital; the Department of \\ Medicine, Harvard Medical School; and the Departments of Microbiology \\ and Pathology, Boston University School of Medicine, Boston, Mass.)
}

Summary. The administration of a carbohydrate-containing diet for 24 hours to rats previously fasted for 3 days led to a twofold increase in total intestinal sucrase and sucrase specific activity. The specific activity of maltase was similarly increased, but lactase activity was unaffected. The sucrose-containing diet led to a greater increase in sucrase than maltase activity, whereas the converse was true of the maltose-containing diet. A carbohydrate-free isocaloric diet led to a slight increase in the total intestinal sucrase, but sucrase specific activity was unchanged. Assay of sucrase activity of mixed homogenates from casein-fed and sucrose-fed rats or fasted and sucrose-fed animals yielded activities that were additive. The Michaelis constant $(\mathrm{Km})$ of the enzyme hydrolyzing sucrose was similar in the fasted, casein-fed, and sucrose-fed rats. The maximal velocity ( $V \max$ ) was twice greater in sucrose-fed as compared to casein-fed or fasted rats, suggesting an increased quantity of enzyme subsequent to sucrose feeding.

Adrenalectomized rats maintained on $1.0 \%$ salt intake had sucrase and maltase levels comparable to those of controls. Steroid administration did not significantly increase their activities. The response to sucrose feeding was similar in both control and adrenalectomized rats, indicative of the absence of steroidal control on sucrase and maltase activity in the adult animal.

Studies using intestinal ring preparations indicated that sucrose hydrolysis by the intact cells proceeded more rapidly when animals were fed sucrose. Additional corroboration of the physiologic significance of the increased enzyme levels in homogenates was afforded by intestinal perfusion studies. Sucrose hydrolysis increased twofold and fructose absorption fourfold in animals fed sucrose when compared to either fasted or casein-fed rats.

\section{Introduction}

The demonstration of isolated deficiencies of the intestinal disaccharidases as well as the nonspecific depression of these enzymes in diverse small bowel diseases has renewed interest in disaccharide absorption (1-5). To date, little is known

* Submitted for publication June 6, 1966; accepted October 20, 1966.

This investigation was supported by research grants T1 AM 5320, National Institute of Arthritis and Metabolic Diseases; CA 02090 and CA 04486, National Cancer Institute; and GMO 9628, National Institute of Gen- about the factors that regulate the tissue levels of these enzymes and their physiologic significance. Marked variability of disaccharidase levels characterizes the peroral biopsy specimen in normal humans and is due in part to variable numbers of

eral Medical Sciences, National Institutes of Health, Bethesda, Md. A preliminary report appeared in Fed. Proc. 1965, 24, 403.

† Present address: Dept. of Medicine, State University of New York (Downstate) and Dept. of Medicine, Maimonides Hospital, Brooklyn, N. Y.

$\ddagger$ Address requests for reprints to Dr. N. Zamcheck, Boston City Hospital, Boston, Mass. 02118. 
epithelial cells and inflammation within the lamina propria. Furthermore, enzyme activity may be influenced by previous dietary experience. In the rat at least, intestinal sucrase (6) and alkaline phosphatase $(7,8)$ can be modified by diet. Although evidence on this point is not available in humans, there is little doubt that enzymatic adaptation occurs in mammalian tissue and that this may be induced by appropriate substrates. However, the relationship of adaptation to physiologic function is not well defined. Thus, depressed levels of disaccharidases can be implicated as functionally significant in disaccharide malabsorption only if the enzyme level is rate-limiting and variations in disaccharidase levels are reflected by changes in disaccharide absorption.

We initiated the present studies 1 ) to determine the influence of diet and adrenocorticoid hormones upon intestinal disaccharidase levels, 2) to define the mechanism, and 3) to study the physiological significance of these changes measured in vitro and in rivo.

\section{Methods}

Male albino rats ${ }^{1}$ (175 to $350 \mathrm{~g}$ ) were kept at constant temperature $\left(70 \pm 1^{\circ} \mathrm{F}\right)$ for at least 1 week before initiation of the experiment, during which time they were fed Purina laboratory chow ad libitum. The rats were fasted but allowed water ad libitum for 3 days, and then they were placed for 24 hours on one of the synthetic diets (Table I). Adrenalectomized rats (maintained with $1 \%$ sodium chloride in their drinking water) were fasted but allowed free access to $1 \%$ sodium chloride solution for 24 hours; then they were placed on one of the synthetic diets for 24 hours.

Homogenate assays. Rats were decapitated and the small bowel rinsed in situ with ice-cold $0.9 \%$ saline. The entire small bowel or the third $10-\mathrm{cm}$ segment distal to the pylorus was removed and homogenized in seven times its volume of cold saline in a glass homogenizer. We assayed samples as described below at various dilutions and different time intervals to ensure linearity of the assays. Although maltose and sucrose are hydrolyzed by several apparently different enzymes with overlapping substrate affinities, for convenience the enzymes that hydrolyze each substrate are referred to collectively as sucrase or maltase.

Sucrose hydrolysis by intestinal rings. The entire small bowel was rinsed in situ with ice-cold saline, removed, everted with a metal probe, and cut into rings weighing 20 to $30 \mathrm{mg}$ each according to the general method of Agar, Hird, and Sidhu (9). After randomization, ten to fifteen rings were placed in an Erlenmeyer

\footnotetext{
1 Charles River Laboratories, Wilmington, Mass.
}

TABLE I

Synthetic diets

\begin{tabular}{lc}
\hline \multicolumn{1}{c}{ Substance } & $\begin{array}{c}\text { Dietary } \\
\text { content }\end{array}$ \\
\hline Sucrose, maltose, glucose, fructose, & $\mathrm{g} / 100 \mathrm{~g}$ diet \\
or vitamin-free casein & 68 \\
Casein (vitamin-free) & 17 \\
Beef fat & 8 \\
Salt mixture* & 4 \\
Cellulose flour & 2 \\
Vitamin powder $\dagger$ & 1
\end{tabular}

* Salt mixture contained $\mathrm{Ca}\left(\mathrm{C}_{3} \mathrm{H}_{5} \mathrm{O}_{2}\right)_{2} \cdot 5 \mathrm{H}_{2} \mathrm{O}, 35 \%$ $\mathrm{CaCO}_{3}, 5.06 \% ; \mathrm{Ca}\left(\mathrm{H}_{2} \mathrm{PO}_{4}\right) \cdot \mathrm{H}_{2} \mathrm{O}, 14.6 \% ; \mathrm{K}_{2} \mathrm{HPO}_{4}, 6.46 \%$; $\mathrm{NaH}_{2} \mathrm{PO}_{4} \cdot \mathrm{H}_{2} \mathrm{O}, 18.76 \% ; \mathrm{NaCl}, 9.34 \% ; \mathrm{MgSO}_{4}, 7.18 \%$; $\mathrm{ZnSO}_{4}, 0.035 \%$; $\mathrm{CuSO}_{4}, 0.039 \%$; KI, $0.00039 \%$; Fe citrate, $3.2 \%$; and $\mathrm{MnSO}_{4} \cdot \mathrm{H}_{2} \mathrm{O}, 0.33 \%$.

+ Vitamin powder contained thiamine, $0.05 \%$; riboflavin, $0.025 \%$; pyridoxine, $0.02 \%$; calcium pantothenate, $0.1 \%$; and nicotinic acid, $0.1 \%$.

flask containing $20 \mathrm{ml}$ of $28 \mathrm{mM} d(+)$-sucrose ${ }^{2}$ and $1 \%$ polyethylene glycol ${ }^{3}(4,000)$ (PEG) in a phosphatesaline buffer ( $\mathrm{pH} \mathrm{7.4)}$ and incubated at $37^{\circ} \mathrm{C}$ in a shaking water bath. Samples of the incubation medium were removed at 30,45 , and 60 minutes and analyzed for PEG, fructose, glucose, and sucrose. An estimate of sucrase activity was obtained by homogenizing a sample of the rings in cold saline and assaying in a phosphatesaline buffer that contained $28 \mathrm{mM}$ sucrose ( $\mathrm{pH} 7.4$ ).

Perfusion studies. Rats were fasted and refed as described above. A general method described by Schanker. Tocco, Brodie, and Hogben was used in the perfusion studies (10). The rat was anesthetized with Pentothal ( $5 \mathrm{mg}$ per $100 \mathrm{~g}$ body weight) and placed in an incubator maintained at $37^{\circ} \mathrm{C}$. A ligature was placed around the pylorus, a small incision was made in the first portion of the duodenum, and a cannula was inserted. After the ileocecal area had been ligated, a polyethylene catheter was inserted into the distal ileum. A solution containing 18 to $20 \mathrm{mM}$ sucrose in $140 \mathrm{mM} \mathrm{NaCl}$ with $1 \%$ polyethylene glycol maintained at $37^{\circ} \mathrm{C}$ was perfused by a constant perfusion pump ${ }^{4}$ for 30 minutes at $1.5 \mathrm{ml}$ per minute, and the effluent was discarded. Six consecutive 10-minute collection periods were obtained; the effluents were assayed for sucrose, glucose, fructose, and PEG as described below. The per cent water absorption was determined from the change in PEG concentration (11).

Analytical methods. Sucrase, maltase, and lactase activities were determined as described by Dahlquist (12) with minor modifications. Sucrase and maltase activities were measured in a $25 \mathrm{mM}$ sodium maleate buffer $(\mathrm{pH}$ 6.2) with the substrate at a $28 \mathrm{mM}$ concentration except where otherwise specified; lactase activity was measured in a phosphate-citrate buffer ( $\mathrm{pH} 4.8$ ) with lactose present at $14 \mathrm{mM}$ concentration. Alkaline phosphatase was measured as described by Moog (13) using $100 \mathrm{mM}$ so-

2 Mallinckrodt Chemical Works, St. Louis, Mo.

3 Union Carbide Corp., New York, N. Y.

${ }^{4}$ Harvard Apparatus Co., Dover, Mass. 


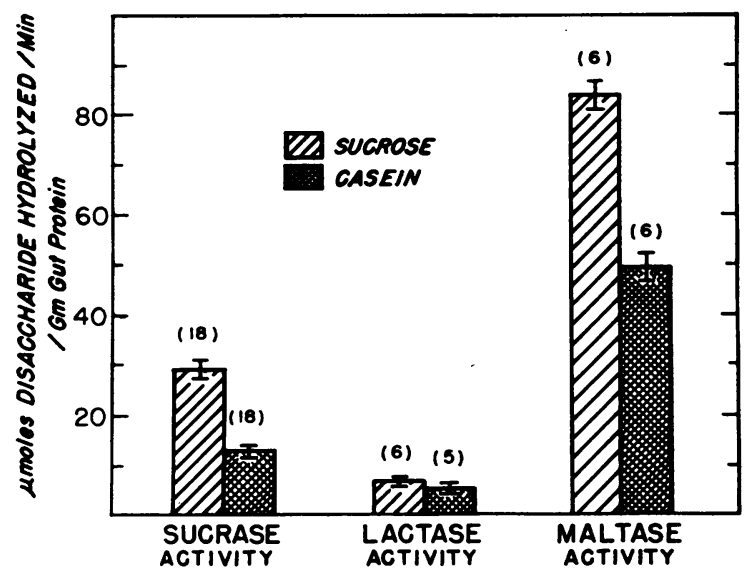

Fig. 1. EFFect of SUCRose and CASEIN FEeding on THE DISACCHARIDASE ACTIVITY OF THE THIRD 10-CM SEGMENT OF THE RAT intestine. Adult male rats were fasted for 3 days and then fed the sucrose or casein diet ad libitum for 24 hours. The third $10-\mathrm{cm}$ segment of the small bowel was homogenized in cold saline and assayed for disaccharidase activity. The substrate concentration in the incubation medium was 14 mmoles per L. Results are plotted as means \pm standard errors. The number of experiments is given in parentheses.

dium diphenyl phosphate ${ }^{5}$ in a barbital buffer $(\mathrm{pH} 9.65)$ with $10 \mathrm{mM} \mathrm{MgCl}_{2}$. A specific enzymatic assay ${ }^{6}$ (glucose oxidase) was used for glucose determinations. The total reducing sugar (fructose and glucose) was measured with dinitrosalicylic acid 7 and the fructose concentration calculated as the difference between total reducing sugar and that attributable to glucose (14). Sucrose was determined from the increase in free glucose after incubation with yeast invertase ${ }^{8}$ in an acetate buffer ( $\mathrm{pH} 4.5$ ) or by the anthrone method (15) after destruction of glucose and fructose by heating in an alkaline $\mathrm{pH}$ for 10 minutes. Protein was measured as described by Lowry, Rosebrough, Farr, and Randall (16), using a bovine albumin ${ }^{9}$ standard. PEG was measured as described by Hydén (17).

\section{Results}

Two groups of adult male rats were fasted for 3 days, and then one was fed the sucrose and the other the casein diet ad libitum for 24 hours. Ingestion of these isocaloric diets and weight gain were similar in both groups. Lactase, sucrase, and maltase activities measured in the third $10-\mathrm{cm}$ segment of the small bowel distal to the pylorus are

5 Fisher Scientific Co., Fair Lawn, N. J.

6 Worthington Biochemical Corp., Freehold, N. J.

7 Eastman Chemical Corp., Rochester, N. Y.

${ }^{8}$ Calbiochem, Los Angeles, Calif.

9 Pentex Inc., Kankakee, IIl. shown in Figure 1. Mean sucrase activity in the sucrose-fed animals was $29.0 \mu$ moles sucrose hydrolyzed per minute per $\mathrm{g}$ gut protein compared to 12.0 in the casein-fed rats. Lactase activity remained similar in both groups of rats. Maltase activity significantly increased in sucrose-fed animals, although the proportionate increase was not so great as that noted for sucrase.

Fifty-one rats were divided into three groups. Each group was fasted for 3 days and then fed 1) a high sucrose, 2) a high maltose, or 3 ) a caseincontaining diet. Both the sucrose- and maltosecontaining diets elicited a significant rise in sucrase and maltase activities as compared to the casein diet (Table II). The sucrose diet elicited a greater rise in sucrase than in maltase, whereas the converse was true of the maltose diet. A comparison of the ratios of maltase to sucrase activities in these groups is shown in Table II. Maltose, although eliciting a rise in both sucrase and maltase activities, did not significantly alter the ratio of their activities from that in the caseinfed controls. Sucrose feedings, however, elicited a greater rise in sucrase than in maltase activity, and the ratio was significantly different from those of the maltose- and casein-fed animals.

The intestinal tract is not a homogeneous organ along its entire length. As the changes in specific activity observed in the selected segments of intestine may result from changes in protein content, the total intestinal sucrase activity was measured. As seen from Table III, feeding the casein diet or the carbohydrate-containing diets for 24 hours elicited a rise in total gut protein compared to the fasted animals. The carbohydrate-containing diet, however, evoked a significant rise in

TABLE II

Effect of sucrose, maltose, and casein feeding on maltase and sucrase activities of the third 10-cm segment of the rat intestine*

\begin{tabular}{|c|c|c|c|}
\hline Diet & Sucrase activity & Maltase activity & $\frac{\text { Maltase }}{\text { Sucrase }}$ \\
\hline & $\begin{array}{c}\text { pmoles sucrose } \\
\text { hydrolyzed } / g \text { gut } \\
\text { protein } / \text { min }\end{array}$ & $\begin{array}{c}\text { pmoles maltose } \\
\text { hydrolyzed } / g \text { gut } \\
\text { protein } / \mathrm{min}\end{array}$ & \\
\hline $\begin{array}{l}\text { Casein } \\
\text { Sucrose } \\
\text { Maltose }\end{array}$ & $\begin{array}{l}23.6 \pm 1.2 \\
53.9 \dagger \pm \pm 2.8 \\
44.3 \dagger \pm 5.2\end{array}$ & $\begin{array}{l}113 \pm 6.2 \\
148 \dagger \ddagger \pm 7.1 \\
178 \dagger \pm 6.2\end{array}$ & $\begin{array}{l}5.02 \pm 0.26 \\
2.93 \dagger \pm 0.13 \\
4.37 \ddagger \pm 0.27\end{array}$ \\
\hline
\end{tabular}

* Results are given as mean values \pm standard errors. There were 17 rats in each group.

$\dagger \mathrm{p}<0.01$ as compared to casein-fed rats.

$\ddagger \mathrm{p}>0.05$ as compared to maltose-fed rats. 
TABLE III

Total intestinal sucrase activity of rats fed various dietary regimens*

\begin{tabular}{|c|c|c|c|c|c|}
\hline Diet & $\begin{array}{l}\text { No. of } \\
\text { animals }\end{array}$ & $\begin{array}{l}\text { Mean } \\
\text { body } \\
\text { wt }\end{array}$ & Total gut protein & Specific activity & $\begin{array}{l}\text { Total intestinal } \\
\text { sucrase activity }\end{array}$ \\
\hline & & $g$ & $g$ & $\begin{array}{c}\text { umoles hydrolyzed } / \mathrm{g} \\
\text { protein } / \mathrm{min}\end{array}$ & umoles hydrolyzed/min \\
\hline Fasted & 15 & 165 & $0.564 \pm 0.031$ & $20.0 \pm 1.79$ & $10.8 \pm 1.27$ \\
\hline Casein & 16 & 164 & $0.723 \pm 0.039$ & $25.8 \dagger \pm 1.30$ & $18.7 \ddagger \pm 1.44$ \\
\hline Sucrose & 16 & 165 & $0.688 \pm 0.031$ & $46.1 \pm \pm 2.74$ & $31.5 t \pm 2.41$ \\
\hline Fructose & 6 & 135 & $0.766 \pm 0.116$ & $45.5 \neq \pm 3.88$ & $33.7 \ddagger \pm 4.54$ \\
\hline Glucose & 7 & 136 & $0.760 \pm 0.071$ & $43.4 f \pm 2.06$ & $27.3 \ddagger \pm 3.10$ \\
\hline Maltose & 16 & 165 & $0.670 \pm 0.040$ & $36.4_{+}^{+} \pm 2.89$ & $23.6 t \pm 1.30$ \\
\hline
\end{tabular}

* Results are expressed as means \pm standard errors.

$\dagger \mathrm{p}<0.05>0.01$ when compared to fasted animals.

$\ddagger \mathrm{p}<0.01$ when compared to fasted animals.

the specific activity of sucrase. The casein-containing diet yielded a minimal increase in sucrase specific activity owing to the increased gut protein in this group. Total intestinal sucrase activity was, however, significantly increased in the caseinfed animals as compared to fasted controls.

Changes in sucrase activity observed with the different dietary regimens may represent changes in the quantity of enzyme present or alterations in the kinetic characteristics of a similar quantity of enzyme. Accordingly, the following studies were performed. Jejunal homogenates from sucroseand casein-fed rats were prepared, and sucrase activity was determined. Portions of each fraction were mixed together; the sucrase activity of the mixed homogenates was measured (Table IV). The sucrase activity of the mixed homogenate was not significantly different from that predicted on the basis of an additive effect. Similar results were obtained from mixed homogenates from sucrose-fed and fasted animals, indicating that the differences observed were not attributable to variations in easily dissociable inhibitors or activators.

TABLE IV

Mean sucrase activity of mixed homogenates from fasted, sucrose-fed, and casein-fed rats*

\begin{tabular}{|c|c|c|c|c|}
\hline & & \multicolumn{3}{|c|}{ Mixed homogenates } \\
\hline & & Obtained & $\begin{array}{c}\text { Theoret } \\
\text { ical }\end{array}$ & $\begin{array}{c}\text { Mean differ- } \\
\text { ence between } \\
\text { pairs } \pm S E\end{array}$ \\
\hline Sucrose & Casein & & & \\
\hline $26.7(6)$ & 15.7 & 21.9 & 21.5 & $0.33 \pm 0.22$ \\
\hline Sucrose & Fasted & & & \\
\hline $32.6(5)$ & 11.3 & 23.8 & 22.6 & $1.2 \pm 0.75$ \\
\hline
\end{tabular}

* The results are expressed as micromoles sucrose hydrolyzed per gram gut protein per minute and are given as the mean value. The number of experiments is given in parentheses.
Intestinal sucrase activity of fasted or sucroseor casein-fed rats was assayed at different substrate concentrations. At each substrate concentration the homogenates from sucrose-fed rats exhibited greater sucrase activity than homogenates from casein-fed and fasted animals (Figure 2). However, the curves approached saturation at similar substrate concentrations. When these data were plotted by the method of Lineweaver and Burk (Figure 3), the $\mathrm{Km}$ of the enzyme or enzymes hydrolyzing sucrose was similar in the fasted and casein- or sucrose-fed rats. The Vmax,

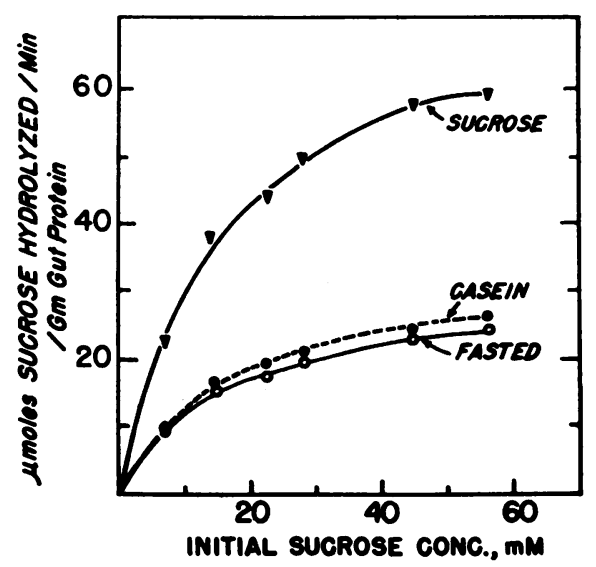

Fig. 2. Sucrase activity of homogenates of entire SMALL INTESTINE OF FASTED, SUCROSE-FED, AND CASEINFED RATS AT VARYing SUbStrate concentrations. Samples were assayed in a maleate buffer ( $\mathrm{pH} \mathrm{6.2)} \mathrm{at} \mathrm{varying}$ substrate concentrations. Incubation was carried out at $37^{\circ}$ in a shaking water bath, and samples were removed at different time intervals to ensure the linearity of the assay. There were three rats in each group; the values listed represent the mean values obtained on duplicate determinations. 


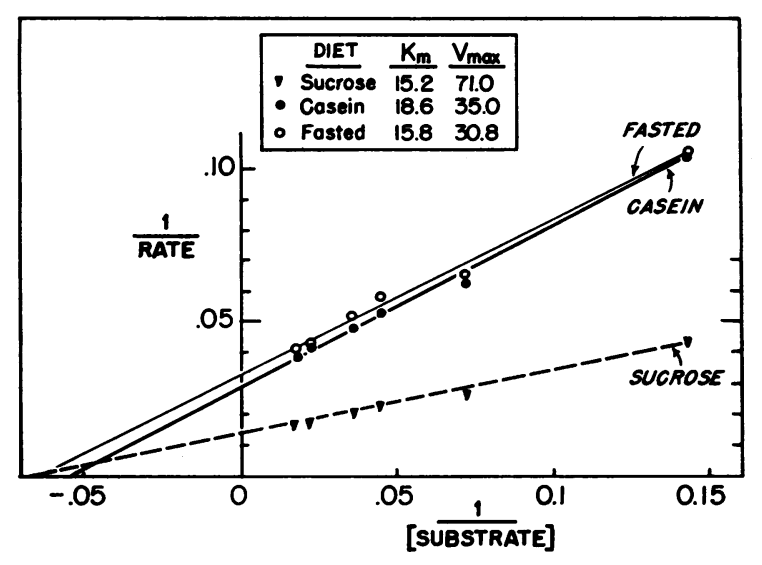

Fig. 3. Lineweaver and Burk plot of data from FIGURE 2. $\mathrm{Km}=$ Michaelis constant $; \mathrm{V} \max =\operatorname{maximal}$ velocity.

however, was twice as great in sucrose-fed as compared to casein-fed or fasted rats.

As corticosteroids have been shown to induce precociously sucrase activity in developing rat intestine (18) and to induce many other mammalian enzymes (19), the effects of adrenalectomy and subsequent steroid replacement were studied ( $\mathrm{Ta}$ ble V). Levels of sucrase and maltase in adrenalectomized rats that were fed casein while being maintained on a $1.0 \%$ salt intake in their drinking water were in the range found in nonadrenalectomized rats fed the casein diet. Cortisone acetate administration ( $3 \mathrm{mg}$ per $100 \mathrm{~g}$ body weight in three divided doses) did not significantly increase their activities. Sucrose feeding, however, elicited a rise in sucrase and maltase activities of an order of magnitude observed in the nonadrenalectomized rats.

To determine whether the rise in intestinal enzymes was limited to sucrase and maltase, we measured intestinal alkaline phosphatase activity. Both the casein and sucrose diets elicited a significant rise in the intestinal alkaline phosphatase. Both diets contained $17 \%$ fat, which presumably was responsible for a rise in intestinal alkaline phosphatase activity (7). This was circumvented by fasting two groups of rats for 3 days; one group had access to a $20 \%$ solution of sucrose for 24 hours, whereas the other had access only to water. Rats drinking the sucrose solution had a significant rise in intestinal sucrase activity, but alkaline phosphatase activity rose only slightly and did not achieve a $5 \%$ level of significance (Table VI).
To determine whether the differences in sucrase levels in homogenates of fasted as compared to sucrose-fed rats were of physiological significance, we measured the rate of sucrose hydrolysis by intact cell preparations using both in vitro and in vivo techniques. In ring preparations, the rate of sucrose hydrolysis proceeded more rapidly with rings prepared from sucrose-fed rats as compared to those of fasted animals (Figure 4).

These findings were further corroborated with intestinal perfusion studies in vivo. Rats fed the different dietary regimens were perfused at a constant rate, and the rates of sucrose, glucose, and fructose appearing in the effluent were measured (Table VII). In the fasted animals, when sucrose was perfused at $28.2 \mu$ moles per minute, 8.0 $\mu$ moles per minute was hydrolyzed, and $5.8 \mu$ moles of fructose per minute appeared in the effluent for a net absorption of $2.2 \mu$ moles of fructose per minute. At a similar perfusion rate, rats fed sucrose for 1 day hydrolyzed $14.4 \mu$ moles of sucrose per minute; $5.5 \mu$ moles per minute of fructose appeared in the effluent for a calculated net absorption of $8.9 \mu$ moles per minute. Perfusion of rats fed sucrose for 7 days yielded similar results. Casein-fed rats hydrolyzed sucrose at a rate between that of the fasted and sucrose-fed animals (10.8 $\mu$ moles per minute), whereas fructose was absorbed at a rate of $2.6 \mu$ moles per minute. Water absorption was similar in all groups.

\section{Discussion}

The present report confirms the observation that diet influences intestinal sucrase, maltase, and al-

TABLE V

Comparative effects of feeding casein, casein + cortisone, and sucrose on jejunal sucrase and maltase activities of adrenalectomized rats*

\begin{tabular}{|c|c|c|}
\hline Diet & Sucrase activity & Maltase activity \\
\hline \multirow{3}{*}{$\begin{array}{l}\text { Casein } \\
\text { Casein }+ \\
\text { cortisone } \\
\text { Sucrose }\end{array}$} & $\begin{array}{c}\text { pmoles sucrose } \\
\text { hydrolyzed } / \mathrm{g} / \mathrm{min}\end{array}$ & $\begin{array}{c}\text { pmoles maltose } \\
\text { hydrolyzed } / \mathrm{g} / \mathrm{min}\end{array}$ \\
\hline & $27.4 \pm 2.1(10)$ & $80.7 \pm 4.1(10)$ \\
\hline & $\begin{array}{l}36.4 \dagger \pm 1.9 \text { (6) } \\
67.1 \pm \pm 2.2(10)\end{array}$ & $\begin{array}{r}84.9 \dagger \pm 3.2 \\
130 \ddagger \pm 8.5(10)\end{array}$ \\
\hline
\end{tabular}

* The third $10-\mathrm{cm}$ segment of small bowel distal to the pylorus was homogenized and assayed for sucrase and maltase. Results are expressed as mean values \pm standard errors. The number of animals is given in parentheses.

$t p>0.05$ as compared to casein-fed rats.

$\ddagger \mathrm{p}<0.01$ as compared to casein-fed rats. 
kaline phosphatase activities (6-8). After 3 days of fasting, rats fed a sucrose or maltose diet exhibited increased specific activity of sucrase and maltase but no change in lactase activity. Sucrose feeding elicited a greater rise in sucrase than maltase, whereas the converse obtained with maltose. Of the three rat intestinal maltases separable by chromatographic techniques, only two have an affinity for sucrose (19). Presumably only the latter two are affected by sucrose feeding, whereas all three are influenced by maltose feeding.

Glucose or fructose feeding alone also increased sucrase activity and has been interpreted as a lack of strict substrate stereospecificity on the part of sucrase. Part of the increase in sucrase activity appears to be related to a nonspecific effect of calories alone or protein per se, since feeding diets devoid of carbohydrate increased both the specific and total gut sucrase activity slightly. The major increase in sucrase activity, however, was noted when either monosaccharides or disaccharides were fed. Although the mechanism for the nonspecific influence of monosaccharides on sucrase activity is not clear, these findings are analogous to observations in bacterial systems in which substances that are not substrates may be potent inducers of enzyme activity (20).

The increase in disaccharidase activities elicited by the carbohydrate-containing diets appears to be a specific effect upon sucrase and maltase and can readily be separated from a nonspecific dietary response. Feeding only liquid sucrose solutions increased sucrase and maltase levels without affecting alkaline phosphatase. The latter was increased along with sucrase and maltase by the solid carbohydrate-containing diet, presumably due

TABLE VI

Effect of $20 \%$ sucrose in the drinking water of fasted rats on sucrase and alkaline phosphatase activities*

\begin{tabular}{|c|c|c|}
\hline & Sucrase activity & $\begin{array}{l}\text { Alkaline phos- } \\
\text { phatase activity }\end{array}$ \\
\hline & $\begin{array}{c}\text { umoles sucrose } \\
\text { hydrolyzed } / \mathrm{g} \text { gut } \\
\text { protein } / \mathrm{min}\end{array}$ & $\begin{array}{c}\text { umoles phenyl- } \\
\text { phosphate } \\
\text { hydrolyzed/gigut } \\
\text { protein/min }\end{array}$ \\
\hline \multirow{2}{*}{$\begin{array}{l}\text { Fasted } \\
\text { Fasted }+ \\
\quad 20 \% \text { sucrose }\end{array}$} & $17.0 \pm 1.0$ & $368 \pm 35(19)$ \\
\hline & $32.2 \dagger \pm 1.74(8)$ & $406 \ddagger \pm 27$ \\
\hline
\end{tabular}

* Results are expressed as mean value \pm standard error. The number of animals is given in parentheses.

$\dagger \mathrm{p}<0.01$ compared to fasted animals.

$\ddagger \mathrm{p}>0.05$ compared to fasted animals.

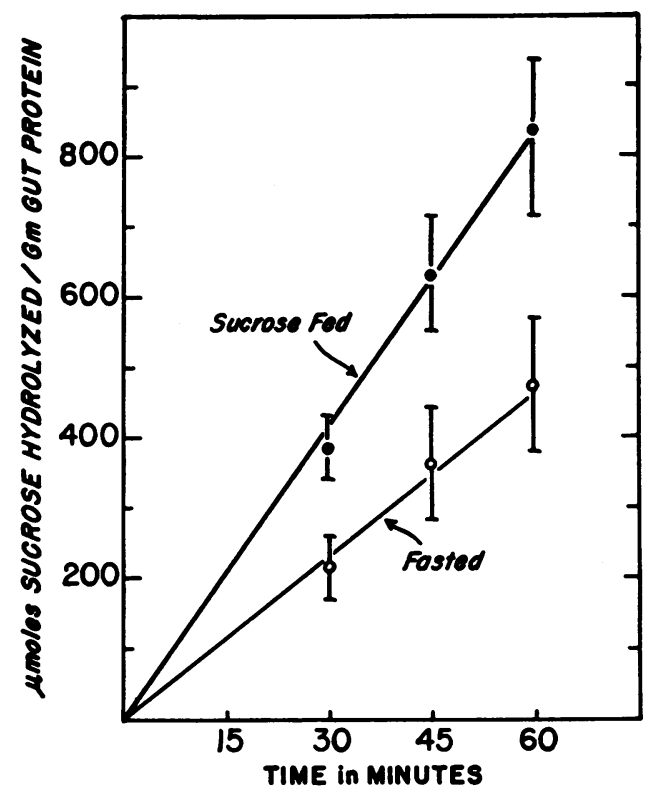

Fig. 4. Sucrose hydrolysis By RINGS OF SMALL BOWEL FROM FASTED AND SUCROSE-FEd RATS. Adult rats were fasted for 3 days and then fed a sucrose diet ad libitum for 24 hours. The entire small bowel was rinsed in situ with ice-cold saline, removed, everted on a metal probe, and cut into small segments. After randomization, 5 to 10 segments were placed in a $50-\mathrm{ml}$ Erlenmeyer flask, which contained $20 \mathrm{ml}$ of a phosphate-saline buffer, $\mathrm{pH} 7.2$, with $25 \mathrm{mM}$ sucrose and $1 \%$ polyethylene glycol (PEG). They were incubated in a shaking water bath at $37^{\circ}$ under continuous oxygenation, and samples of the medium were removed at $0,30,45$, and 60 minutes and analyzed for sucrose, glucose, fructose, and PEG. The rate of sucrose hydrolysis was calculated from the rate of fructose appearance in the incubation medium. Results are given as mean values \pm standard error. There were seven rats in each group.

to the fat content (6). Furthermore, although both the casein and carbohydrate diets increased gut protein equally, only the latter diet significantly increased the specific activity of the two disaccharidases.

Gut rings from rats fed sucrose exhibited an increased ability to hydrolyze sucrose proportional to the increase in enzyme levels observed in gut homogenates. This was further substantiated by in vivo perfusion studies. Compared to fasting rats, casein feeding increased the hydrolysis of sucrose perfused through the intestinal lumen, thus correlating with the increased total intestinal sucrase activity. Substitution of sucrose for casein further increased disaccharide hydrolysis to twice that of the fasted animals, again correlating 
TABLE VII

Small bowel sucrose perfusions of fasted and sucrose- and casein-fed rats*

\begin{tabular}{|c|c|c|c|c|c|c|}
\hline \multirow[b]{2}{*}{ Group } & \multirow{2}{*}{$\begin{array}{l}\text { Sucrose in- } \\
\text { fusion rate }\end{array}$} & \multirow{2}{*}{$\begin{array}{c}\text { Water } \\
\text { absorption }\end{array}$} & \multicolumn{2}{|c|}{ Effluent } & \multirow{2}{*}{$\begin{array}{c}\text { Sucrose } \\
\text { hydrolysis }\end{array}$} & \multirow{2}{*}{$\begin{array}{c}\text { Fructose } \\
\text { absorption }\end{array}$} \\
\hline & & & Sucrose & Fructose & & \\
\hline & 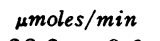 & $\%$ & \multicolumn{2}{|c|}{ umoles/min } & umoles/min & umoles/min \\
\hline 3-day fast (17) & $28.2 \pm 0.3$ & $5.4 \pm 0.8$ & $20.2 \pm 0.5$ & $5.8 \pm 0.4$ & $8.0 \pm 0.4$ & $2.2 \pm 0.3$ \\
\hline $\begin{array}{l}\text { 3-day fast }+1 \text {-day } \\
\text { casein diet }(8)\end{array}$ & $28.8 \pm 0.7$ & $6.8 \pm 2.1$ & $18.0 \pm 1.1$ & $8.2 \pm 1.0$ & $10.8 \dagger \pm 0.8$ & $2.6 \ddagger \pm 0.7$ \\
\hline $\begin{array}{l}\text { 3-day fast }+1 \text {-day } \\
\text { sucrose diet }(8)\end{array}$ & $28.2 \pm 0.3$ & $7.0 \pm 1.6$ & $13.8 \pm 0.7$ & $5.5 \pm 0.4$ & $14.4 \S \pm 0.7$ & $8.9 \S \pm 0.7$ \\
\hline $\begin{array}{l}\text { 3-day fast }+7 \text {-day } \\
\text { sucrose diet }(4)\end{array}$ & $28.3 \pm 0.9$ & $7.2 \pm 2.4$ & $11.4 \pm 3.0$ & $6.0 \pm 0.8$ & $16.9 \S \pm 2.2$ & $10.9 \xi \pm 2.4$ \\
\hline
\end{tabular}

* Results are expressed as mean values \pm standard errors. The number of animals per group is in parentheses.

$\dagger \mathrm{p}<0.01$ when compared to fasted rats.

$\ddagger \mathrm{p}<0.05$ when compared to fasted rats.

$\S \mathrm{p}<0.01$ when compared to fasted and casein-fed rats.

with the greater increase in total intestinal sucrase activity elicited by sucrose feeding.

Glucose derived from sucrose hydrolysis in fasted and casein- and sucrose-fed rats was almost completely absorbed as minimal quantities of glucose appeared in the ileal effluent. Fructose, however, was not completely absorbed. In fasted rats approximately $25 \%$ of the fructose liberated by hydrolysis was absorbed. In casein-fed animals, the quantity of fructose formed subsequent to sucrose hydrolysis increased slightly and was followed by a proportional increase in fructose absorption. In the sucrose-fed rats, twice as much sucrose was hydrolyzed as compared to fasted animals. However, four times as much fructose was absorbed. This can be explained in part by the higher luminal concentration of fructose achieved in the sucrose-fed rats and the greater fructose absorption in sucrose-fed as compared to fasted animals (21). Thus, changes in intestinal sucrase activity paralleled an increased ability of the intestine to both hydrolyze this substrate and absorb constituent monosaccharides.

Alterations in cell permeability subsequent to carbohydrate feeding cannot be discounted in the present study. Increased cell permeability may allow more rapid access of the disaccharide to the active enzyme site within the cellular compartments-a postulated prerequisite to hydrolysis into constituent monosaccharides $(22,23)$. With intact cell preparations, Dahlqvist and Thomson
(24) have shown that at low substrate concentrations the limiting step is the rate at which the substrate molecules traverse the cell boundary. As the substrate concentration is increased, the activities of homogenates and intact cells approach each other with a similar Vmax. At 28 mmoles per $\mathrm{L}$, the concentration employed in this study, the rate of cellular entry may be rate-limiting. However, it is unlikely that a twofold increase in sucrose hydrolysis could be explained entirely on the basis of altered cell permeability.

On the other hand, the entry of disaccharides into a cellular compartment before hydrolysis has not been clearly delineated. Indeed, it has been suggested that the disaccharidases may be situated at the luminal surface of the plasma membrane on the microvillus (25). Hydrolysis may thus be totally or at least partially intraluminal. In this case, the increased rate of sucrose hydrolysis observed in vivo is explained entirely by the increase in enzyme activity observed in homogenates.

In mammalian systems, enzymatic adaptation may occur via several mechanisms, i.e., a change in the affinity of the apoenzyme for the cofactor, new enzyme synthesis, or an increased quantity of enzyme subsequent to a decreased degradative rate $(26,27)$. The increased disaccharidase activity observed in these studies is presumably secondary to an increase in the quantity of enzyme. The additive effects observed when mixed homogenates from fasted and sucrose-fed rats were assayed are 
indirect evidence for an increased quantity of enzyme. The similar $\mathrm{Km}$ of the enzymes hydrolyzing sucrose in both fasted and sucrose-fed rats with a twofold greater Vmax in the latter animals is best explained by the presence of twice the quantity of enzyme in the sucrose-fed rats. Direct confirmation of this hypothesis would require assay of the quantity of enzymes by means independent of activity measurements, as has been shown immunologically with other enzymes $(28,29)$.

It has been suggested that the mechanism regulating enzyme levels in the adult may be similar to those regulating the accumulation of the enzyme in the developing organism (29). Although rat intestinal sucrase may be precociously induced by steroids (19) and its appearance delayed in an adrenalectomized rat $(30)$, sucrase and maltase levels in the adult were not affected by adrenalectomy or steroid administration. Rat intestinal maltase has been previously observed to be unaltered after adrenalectomy (31). However, as the half-lives of the intestinal sucrases are unknown, caution must be exercised in the interpretation of the lack of steroidal stimulation. Schimke, Sweeney, and Berlin (32) have shown that the rise in enzyme activity after steroid or substrate administration is related to the half-life of the enzyme. The lack of steroid stimulation may merely indicate a prolonged half-life, so that during the period of observation after the stimulus has been applied only a small portion of the enzyme molecules have had a chance to turn over. However, as a 24 -hour fast leads to a $50 \%$ reduction in intestinal sucrase, it would appear that these enzymes are turning over at a rapid rate.

The histology of the small intestine from fasted and casein- and disaccharide-fed animals did not significantly differ. However, it is possible that even during short periods of dietary manipulation, changes in intestinal epithelial cell population may occur as the epithelium is turning over at a rapid rate $(33,34)$. Consequently, measurements of the total epithelial cell population would be required to demonstrate that the en- zyme changes observed represented a change in the number of enzyme molecules per cell rather than an increase in cell population.

In the absence of such measurements, enzyme activity is expressed in terms of wet or dry weight or of nitrogen content. Clinical interpretation of these results is further limited when they are obtained on fragments of human intestinal mucosa. In addition to the epithelial cells, many other cellular constituents of these biopsy specimens including inflammatory infiltrates of the lamina propria are included in homogenates prepared for enzyme analysis. Since it is accepted that disaccharidase activity resides in the brush border of the epithelial cells, the enzymatic activity may be artifactually lowered by the protein contribution of inflammatory cells. An additional factor contributing to the variability noted in the peroral biopsy specimens of normal individuals may relate to the dietary intake preceding the biopsy. Moreover, patients who experience symptoms after the intake of certain food products are likely to refrain from them, so that any depression of measured physiological function may result in part at least from lack of suitable "substrates" induction. It would appear to be important to determine whether dietary factors similarly influence disaccharidases and disaccharide absorption in human subjects. Indeed, changes in intestinal disaccharidases have been reported in human subjects after periods of prolonged fasting (35). Previous attempts to induce lactase activity in deficient adults by feeding milk have not been successful (36). However, lactase may be less responsive to dietary manipulation, as evidenced by the failure to acutely induce lactase activity in experimental animals. Under conditions of prolonged ingestion of large quantities of lactose, total lactase activity in rats has been reported to increase, secondary to an increase in total gut weight and length, but without an increase in lactase specific activity $(37,38)$. Conversely, others have reported a statistically significant increase in lactase activity after prolonged (6 to 9 weeks) ingestion of lactose (39). 


\section{Acknowledgments}

We would like to acknowledge the invaluable assistance of Mrs. Joan Kenney, Miss Joan Zecker, and Mr. Paul Colon.

\section{References}

1. Durand, P. Lactosuria idiopathica in una paziente con diarrea cronica ed acidosi. Minerva pediat. 1958, 10, 706.

2. Holzel, A., V. Schwarz, and K. W. Sutcliffe. Defective lactose absorption causing malnutrition in infancy. Lancet 1959, 1, 1126.

3. Weijers, H. A., J. H. Van de Kamer, W. K. Dicke, and J. Ijsseling. Diarrhea caused by deficiency of sugar splitting enzymes. Acta paediat. (Uppsala) $1961,50,55$.

4. Dahlqvist, A. Specificity of the human intestinal disaccharidases and implications for hereditary disaccharide intolerance. J. clin. Invest. 1962, 41, 463.

5. Plotkin, G. R., and K. J. Isselbacher. Secondary disaccharidase deficiency in adult celiac disease (nontropical sprue) and other malabsorption states. New Engl. J. Med. 1964, 271, 1033.

6. Blair, D. G. R., W. Yakimets, and J. Tuba. Rat intestinal sucrase. II. The effects of rat age and sex and of diet on sucrase activity. Canad. J. Biochem. 1963, 41, 917.

7. Tuba, J., and M. I. Robinson. The response of intestinal alkaline phosphatase of fasted rats to forced feeding of fat. J. biol. Chem. 1953, 203, 947.

8. Tuba, J., and N. Dickie. The role of alkaline phosphatase in intestinal absorption. II. The effects of various carbohydrates on levels of the enzyme in intestinal mucosa. Canad. J. Biochem. 1954, 32, 621.

9. Agar, W. T., F. J. R. Hird, and G. S. Sidhu. The uptake of amino acids by the intestine. Biochim. biophys. Acta (Amst.) 1954, 14, 80.

10. Schanker, L. S., D. J. Tocco, B. B. Brodie, and C. A. M. Hogben. Absorption of drugs from the rat small intestine. J. Pharmacol. exp. Ther. 1958, $123,81$.

11. Jacobson, E. D., D. C. Bondy, S. A. Broitman, and J. S. Fordtran. Validity of polyethylene glycol in estimating intestinal water volume. Gastroenterology 1963, 44, 761.

12. Dahlqvist, A. Method for assay of intestinal disaccharidases. Analyt. Biochem. 1964, 7, 18.

13. Moog, F. Alkaline and acid phosphomonoesterase activity in chick embryos. J. cell. comp. Physiol. 1946, 28, 197.

14. Sumner, J. B. The estimation of sugar in diabetic urine, using dinitrosalicylic acid. J. biol. Chem. 1924, 62, 287.

15. Scott, T. A., Jr., and E. H. Melvin. Determination of dextran with anthrone. Analyt. Chem. 1953, 25, 1656.
16. Lowry, O. H., N. J. Rosebrough, A. L. Farr, and R. J. Randall. Protein measurement with the Folin phenol reagent. J. biol. Chem. 1951, 193, 265.

17. Hydén, S. A. A turbidometric method for the determination of higher polyethylene glycols in biological materials. Ann. roy. agricul. Coll. Sweden 1955, 22, 139.

18. Doell, R. G., and N. Kretchmer. Intestinal invertase: precocious development of activity after injection of hydrocortisone. Science 1964, 143, 42.

19. Dahlqvist, A. Rat-intestinal dextranase. Localization and relation to the other carbohydrases of the digestive tract. Biochem. J. 1963, 86, 72.

20. Monod, J. Remarks on the mechanism of enzyme induction in Enzymes: Units of Biological Structure and Function. Henry Ford International Symposium. New York, Academic Press, 1956, p. 7.

21. Broitman, S. A., J. J. Deren, and N. Zamcheck. Dietary influence on intestinal sucrase activity, sucrose hydrolysis and absorption in the rat. Fed. Proc. 1966, 25, 321.

22. Miller, D., and R. K. Crane. The digestive function of the epithelium of the small intestine. I. An intra cellular locus of disaccharide and sugar phosphate ester hydrolysis. Biochim. biophys. Acta (Amst.) 1961, 52, 281.

23. Miller, D., and R. K. Crane. The digestive function of the epithelium of the small intestine. II. Localization of disaccharide hydrolysis in the isolated brush border portion of intestinal epithelial cells. Biochim. biophys. Acta (Amst.) 1961, 52, 293.

24. Dahlqvist, A., and D. L. Thomson. The hydrolysis of sucrose by intact and homogenized cells of rat small intestine. Influence of $\mathrm{pH}$ and substrate concentration. Biochim. biophys. Acta (Amst.) 1964, 92, 99.

25. Crane, R. K. Enzymes and malabsorption: a concept of brush border membrane disease. Gastroenterology 1966, 50, 254.

26. Greengard, O., and P. Feigelson. The activation and induction of rat liver tryptophan pyrrolase in vivo by its substrate. J. biol. Chem. 1961, 236, 158.

27. Feigelson, P., and O. Greengard. Immunochemical evidence for increased titers of liver tryptophan pyrrolase during substrate and hormonal enzyme induction. J. biol. Chem. 1962, 237, 3814.

28. Kenney, F. T. Induction of tyrosine- $\alpha$-ketoglutarate transaminase in rat liver. III. Immunochemical analysis. J. biol. Chem. 1962, 237, 1610.

29. Greengard, O., M. A. Smith, and G. Acs. Relation of cortisone and synthesis of ribonucleic acid to induced and developmental enzyme formation. J. biol. Chem. 1963, 238, 1548.

30. Jirsová, V., and A. Heringová. Effect of aldosterone and corticosterone on $\beta$-galactosidase and invertase activity in the small intestine of rats. Nature (Lond.) 1965, 206, 300. 
31. Levin, R. J., H. Newey, and D. H. Smyth. The effects of adrenalectomy and fasting on intestinal function in the rat. J. Physiol. (Lond.) 1965, 177, 58.

32. Schimke, R. T., E. W. Sweeney, and C. M. Berlin. An analysis of the kinetics of rat liver tryptophan pyrrolase induction: the significance of both enzyme synthesis and degradation. Biochem. biophys. Res. Commun. 1964, 15, 214.

33. Thaysen, E. H., and J. H. Thaysen. Morphological changes in the gastrointestinal tract of the white rat following inanition. Acta path. microbiol. scand. 1949, 26, 370.

34. Hooper, C. S., and M. Blair. The effect of starvation on epithelium renewal in the rat duodenum. Exp. Cell Res. 1958, 14, 175.

35. Knudsen, K. B., H. M. Bellamy, R. R. Lecocq, E. M. Bradley, and J. D. Welsh. The influence of fast- ing and refeeding on jejunal disaccharidases. Clin. Res. 1966, 14, 300.

36. Cuatrecasas, P., D. H. Lockwood, and J. R. Caldwell. Lactase deficiency in the adult: a common occurrence. Lancet 1965, 1, 14.

37. Fischer, J. E. Effects of feeding a diet containing lactose upon $\beta$-D-galactosidase activity and organ development in the rat digestive tract. Amer. $\mathrm{J}$. Physiol. 1957, 188, 49.

38. Huber, J. T., R. J. Rifkin, and J. M. Keith. Effect of level of lactose upon lactase concentrations in the small intestines of young calves. J. Dairy Sci. 1964, 47, 789.

39. Giradet, P., R. Richterich, and I. Antener. Adaptation de la lactase intestinale à l'administration de lactose chez le rat adulte. Helv. physiol. Pharmacol. Acta 1964, 22, 7. 